\title{
ANALYSIS OF THE MEANING OF ATA PE'ANG KO ATA ONE IN MANGGARAI CULTURE (TRADITION)
}

\author{
Sirilus ligu (Corresponding Author) \\ Letters Faculty, Kanjuruhan University of Malang \\ Jl. S. Supriyadi 48 Malang 65148, East Java, Indonesia \\ Phone: - $\quad$ E-mail: -
}

\begin{abstract}
Manggarai is an ethnic group who lived in the west side of Flores islands. As an ethnic group they have custom which was certainly precious and inheritance from generation to generation. At traditional ceremonies they used Manggarai language (tombo manggarai) and there are so many terms contained in the language. One of the terms which was inheritance of the Manggarai accentors and thrive in the life of Manggarai society was ata pe'ang ko ata one. The research used of qualitative method. Meaning was of essential concerned to the qualitative. The aim of this study here was to investigate the meaning of social phenomena as experienced by the people themselves. Most of the data in this study got by using interview between researcher and informants and in validity of data the researcher used data triangulation and methodological triangulation. The resulted of the study; the term of ata pe'ang-ata one, still close related to the status of authority in managed the household, the genes, and the rights of ownership. Ata pe'angata one was symbolism language which used when a baby birth in Manggarai socitey. Ata pe'ang (outsiders) was symbol to infants who sex female while ata one (insiders) was symbol to infants who sex male. Along with development of the era, traditional ceremony at the moment that baby birth inch by inch not used by Manggarai society. The researcher suggests that this study can be used as an example in pragmatic, meaning and semiotic and in order to this research to develop theory about pragmatic, meaning and semiotic. In practical the researcher suggests to the English students, lecturer, and further researcher in order that will be using this study as a reference and the study also can upgrade their knowledge.
\end{abstract}

Key Words: Meaning, Ata pe'ang-ata one and Manggarai Culture 


\section{Introduction}

Manggarai is a region situated in the west side of Flores islands and it is also an ethnic group which although the territory divides into three regencies however they are similar in the culture. We can found the culture similarity of Manggarai societies in language, customs, beliefs, and norms and so on. As an ethnic group the Manggarai society have custom which certain precious and it is inheritance from generation to generation. We can say the inheritance as Manggarai culture.

Traditional ceremonies are commonly held by Manggarai society are series of life or a part of people's lives; hence all the ceremonies than as traditional ceremonies, but also serves as an educational community. There are so many traditional ceremony in Manggarai society and in general, traditional ceremonies of the

Manggarai Society can be dividing into 3 (three) parts, among them: (1) Traditional ceremony at the moment that Birth, (2) Traditional ceremony when life (the life) (3) Traditional ceremony at the moment that pass away. In this study the researcher will be discuss about traditional ceremony at the moment that birth especially whelping ceremony. When a baby was born in Manggarai and if the baby already crying so her husband or the old man go outside of the house and banging on the wall of the house three or four times, at the same time saying " ata pe'ang ko ata one" (outsiders or insiders). Based on the description above, the writer wants to conduct research on the meaning of ata peang ko ata one in Manggarai culture especially in the whelping ceremony and its influence. 


\section{Literature review}

According to Tylor's Culture is complex whole which includes knowledge, beliefs, arts, morals, law, customs, and any other capabilities and habits acquired by a human as a member of society. Koentjaraningrat explained that Culture covered whole total from mind, work and human output work which does not take root to his/her instinct. Human being can get dressed, talk, have a certain attitude and act in accordance with in spite of figuratively, sign, symbol, totem, because that is all reflected on culture. Hartoko explain that sort of thing to reflect as the way society pattern life which completely dependent on the other world, ancestor world, which in symbol by the totems. The expressions also in applicant at Manggarai culture (Nggoro 2006:11).
According to Kluckhohn, there are 7 elements of culture which considered cultural universals among them Equipment and tools of human life, Livelihood and economic system, Social system, Language, Art, Knowledge system and Religion/believe system (Soekanto 2012:150).

Characteristic of Manggarai culture also has cultural universals (Dagur 1997). In this study the researcher will be explain more about (1) Social system; covered genetic relationship/kinship system, organization politic, law system, and marriage system, Language; covered spoken and written, and

Religion/believes system; covered belief, especially about family relation, marriage system, language, believes system of the Manggarai society. 
Language is the system of sounds and words used by humans to express their thoughts and feelings (Hornby, 1995). The term 'language' can be used to refer to a variety of concepts / things, such as "the particular form of words and speech used by the people of a country, area or social group", or "the method of human communication using spoken or written words" (Dostert: 2009).

Language is vital aspect in the life of all beings, including human being. Language is used as the main instrument of communication; it cannot be free from human being's daily life.

Linguistics is the scientific study of language or of particular languages (Hornby 1995). There are some scopes of linguistics and one of them is semantics. Semantics is the systematic study of meaning and linguistic semantics is the study how languages organize and express meanings. Based on the explanation we can say that meaning is the message we should get from something we read or hear. Semantic is the study of meaning in language. When a sentence is spoken in a particular context by a certain speaker and is directed to a hearer, the sentence is called an utterance. Utterance meaning is also called pragmatic meaning that means the meaning of a sentence when it is used in communication by a speaker and hearer. Linguistics makes a distinction between semantics and pragmatics. According to linguists, semantics is defined as the study of word meaning and sentence meaning without any relation to context. Pragmatics is the study of utterances meaning, sentences which are used in communication, and also the study of meaning in language 
interaction between a speaker and a hearer (Adisutrisno 2008).

We are all necessarily interested in meaning. We wonder about the meaning of a new word. Sometimes we are not sure about the message we should get from something we read or hear, we are concerned about getting our own messages across to others. There are three disciplines are concerned with the systematic study of meaning in itself: psychology, philosophy and linguistics and their particular interests and approaches are different (Kreidler 1998). In this study the researcher only explain about linguistics. In daily Manggarai society uses Manggarai language (tombo manggarai).

Kinship/family relatives understood as the relationship because of blood ties or marriage, because the neighboring place to stay, and relationships of daily life (Nggoro 2006:49). In many societies where kinship connections are important, there are rules, though they may be expressed or be taken for granted. There are four main heading that anthropologists use to categorize rules of descent. They are: (a) bilateral descent or two sided descent affiliates an individual more or less equally with relatives on his father's and mother's sides. (b) Unilineal rules affiliates an individual through the descent of one sex only, that is, either through males or through females. They are subdivided into two: patrilineal (male) and matrilineal (female). Most societies are patrilineal. (c) Ambilineal (or Cognatic) rule affiliates an individual with kinsmen through the father's or mother's line. (d) Double Descent refers to societies in which both the patrilineal and 
matrilineal descent group are recognized. (Wikipedia accessed on 23 Oktober 2014).

Manggarai kinship system is patrilineal (Deki 2011). Patrilineal kinship system is the kinship system which takes the line of kinship of the men (fathers). Nggoro (2006:48) explained that there are some family relations that use in Manggarai culture among them: (a) Ase ka'e/Wa'u. Ase ka'e is family relation which occurs based on father's lineage. (b) Woenelu. Woenelu is family relations which occur based on marital relation. (c) Pa'ang ngaung. Pa'ang ngaung is family relations which occur based on habitation wherein the society lives in same place.

\section{Research Methodology}

Research Design
This research uses qualitative method. Qualitative research is descriptive. It is because the data collected are in the form of words or pictures rather than numbers. Meaning is of essential concern to the qualitative. In other words, according to Erickson qualitative researches are concerned with what are called participant perspectives (Wahyuni 2011:12). The aim ofthis study here is to investigate the meaning of social phenomena as experienced by the people themselves. This was proved by Malterud (Wahyuni 2011:2) who defined that the qualitative research also called naturalistic inquiry, developed within the social and human sciences, and refered to theories on interpretation (hermeneutics) and human experience (phenomonology). They include various strategies for systematic collection, organization and interpretation of textual material 
obtained while talking people or through observation.

\section{Data and Data Source}

Data source in this study are traditional ceremony in Manggarai culture especially whelping ceremony in Manggarai tradition and the other ceremony which related and support with this study.

The data of this study are spoken languge in form of phrase which used in rituality in Manggarai culture especially the meaning of ata peangata one.

\section{Technic of Data Collection}

The main instrument in this study is the researcher himself. Cresswell 1994 states that the qualitative research is the primary instrument for the data collection and the data analysis. Therefore, the researcher plays the important role on this research because the researcher will be the only one instrument that analyzes the data.

Besides, in this study will use interview as research instruments. Interviews are an attractive proposition for the project researcher. Interviews are something more than conversation. They involve a set of assumptions and understandings about the situation which are not normally associated with a casual conversion.

Data Analysis

Miles and Huberman (1994) suggest that qualitative data analysis consists of three procedures: (1) Data reduction. Data reduction refers to the process of selecting, focusing, simplifying, abstracting and transforming the data that appear in written field notes or transcriptions. This refers to the process whereby the mass of 
qualitative data the researchers may obtain - interview transcripts, field notes, observations etc. - is reduced and organised, for example coding, writing summaries, discarding irrelevant data and so on. (2) Data display. In the data display the researchers will be use code of the data. To draw conclusions from the mass of data, Miles and Huberman suggest that a good display of data, in the form of tables, charts, networks and other graphical formats is essential. This is a continual process, rather than just one to be carried out at the end of the data collection. (2) Conclusion drawing/verification. The analysis should allow you to begin to develop conclusions regarding your study. These initial conclusions can then be verified, that is their validity examined through reference to your existing field notes or further data collection. In verification of data the researchers will be use triangulation.

\section{Findings}

The Description of Ata pe'angata one which Use At Whelping Ceremony in Manggarai Tradition

In this study the researcher attempt to excavate and pour through an article about the traditional ceremony when birth, especially about the meaning of the phrase ata pe'ang-ata one that is used when a baby is born in Manggarai, especially Kolang region. Be related to the case talked about also, the researchers will not discuss how the customs process at birth, but researchers only analyzed the meaning of the terms ata pe'ang-ata one that used when whelping. Before the existence of East Nusa Tenggara government regulation through 
the health department of East Nusa Tenggara on maternity especially the suggestion to give birth in a health facility in 2010 , the majority of people Manggarai give birth in their own homes. For society whose baby's birth in their own homes then the expression ata pe'angata one must be used because it is closely related to the seki (custom rules) and if it is not used then there will be itang (caused when not using custom/phrase ata pe'ang-ata one).

In this study, researchers did not discuss the process of giving birth at health facility, but to discuss the process of child birth in their own homes. When a baby is born in Manggarai and if the baby who was born is already crying so her husband or the old man go outside of the house and banging on the wall of the house three or four times, at the same time saying " ata pe'ang ko ata one" (outsiders or insiders). Usually the number of blows to wall and amount the mention of the expression ata pe'ang ko ata one adapted to the seki (custom rules) from the family which pertinent. For example, in Kolang region the societies use seki 4 , then the number of blows to the wall and the mention "ata pe'ang ko ata one?" also, as much as 4 times.

Then the women who were in the house, especially in which is right the baby's room or place of birth (usually indigenous medical practitioner maternity and older woman or who assist in the birth process) replied: ata pe'ang when the baby who was born female. Why the women called ata pe'ang? One of the cores which deepest in the term/expression that she is sex female and form the outer circle in making love. She is out of the 
deepest core and wrap/ did up the embryo to form the life so-called ata pe'ang. Then when the baby who was born are male then they answered ata one. After ask a question "ata pe'ang ko ata one?" And banging on the wall of the house then replied as much adapted to the seki, so held process of cutting navel rope.

Manggarai society called male ata one because as deep once, male genitalia (penis) when making love/during sexual intercourse be in the womb. In addition, men which put descended.

Although the process of child birth in Manggarai divided into two parts, but in the treatment of indigenous people in everyday life of the Manggarai society there is no difference. It is because Manggarai society embraced patrilineal system. The term ata pe'ang-ata one also legalize patrilineal system which prevailing in Manggarai.

Nevertheless, it does not mean that the question/this expression will not be used and have no connection with traditional processes in the life and death of the Manggarai society. For example, the number of strokes walls and question ata pe'angata one will affect the traditional ceremony when the person passed away. At the time of death, after the person is buried, then the customs in Manggarai terms haung ta'a will be carried out in accordance with the custom event at birth. The expression of ata pe'ang-ata one, still close related to the status of authority in managing the household, the genes, and the rights of ownership. The third part of these traditional ceremonies, mutual related to each other. 
Ata pe'ang ko ata one is a spoken language which is used when a baby birth in Manggarai tradition. It is a phrase and it's also used only when a baby birth ceremony.

The Lexical Meaning of Ata pe'ang-ata one in Manggarai Tradition

In this part the researcher will be discuss ata pe'ang ko ata one expression without any relation to the context wherein the context in the case is whelping ceremony in Manggarai tradition. According to lexical ata pe'ang ko ata one means:

Ata: Other people. So the meaning of words can be said ata has no relationship at all.

Pe'ang: outside. So the word pe'ang can be said to be outside.

Ko: or
One: in. So the word one can be said that to be inside.

So, based on the meaning of the word: ata pe'ang, is other people who are outside while ata one means other people who were inside.

The Traditional Law Value Which Is There In Ata Peang-Ata One Expression Which Use At Whelping Ceremony in Manggarai Tradition

Based on the result of the research, the dominant value contained in ata pe'ang-ata one expression is the religion value. Before 100 years ago, before the religions that now exist in Manggarai, the ancestors of Manggarai society have genuine belief which they believe that nature has the power, so everything that they should believe in and up hold of the force nature. The force of nature called the highest form of so- 
called Supreme Being Mori

Kraeng jari agu dedek (God the creator). Ata pe'ang ata one was actually closer to religious values. It is because, if not made, then they believe there is will be itang (consequences of dereliction if not do it).

In addition there is a law value. The expression of Ata pe'ang ko ata one (insiders, outsiders) legalized patrilineal system which prevailing in Manggarai society and assert that there is a strict separation between man and women.

The Pragmatic Meaning of Ata pe'ang ata one Which Use at Whelping Ceremony in Manggarai Tradition

In this part the researcher will be discuss ata pe'ang ko ata one expression with any relation to the context wherein the context in the case is whelping ceremony in Manggarai tradition.
The meanings of ata pe'ang are:

According to the Manggarai people, the woman is hiri lele, so based on the Manggarai tradition rules, a daughter when she married then she will go to keep up with her husband moved to the house / home and become part of her husband's family as well as forming a new generation in the family pertinent. It is a concrete manifestation of ata pe'ang.

When she is married, would to keep up with seki (custom rules) her husband. Daughter (ata pe'ang), will legal to keep up with her husband's family seki pass through "tempang pitak" (clean mud) ceremony. The purposed of the "tempang pitak" (clean mud) ceremony is to begging to the ancestors that all descended diseases far off, loosing upon by the blood of pigs and all the traditions of forbidden by taboo (seki) of women's family declare loosing 
upon and immediately to keep up with seki of men's family.

When she is married, she also does not have the authority again to have the inheritance of her parents. It is because she will be getting inheritance in place or her husband's family. If the actual fundamental in terms of inheritance, according to old habits and remain valid in general until now, in fact ata pe'ang had no right at all to accept the inheritance parents. But in its development, as the influence of positive law that which have the right to receive all of the inheritance that is the biological child, then now in practice in some specific family, heritage also distributed to daughter in the form of wida (giving/gift). But, it is depend on the attitude of the heart that is full of peace either party nara (brother) and weta (sister), but who actually have the right to receive an inheritance that is ata one.
In practice at the family which there is no boys, then Which accept inheritance is daughter of the pertinent family, but which organize is family from anak rona (father's family), with the result that do not to overly take sides on certain woe (sister/daughter). Then, if later the sister stated that she hand over the inheritance to his cousin, then when she is visit to the home of her parents or have duty to wale Sida then they staying within the house of her brother/ cousin.

Ata one meanings are:

According to the Manggarai people, the man is hiri bongkok so as a rule of customary the Manggarai, he was going to successor descendants his parents'. When he is married, then he would take his wife to the house/home and his wife will follow seki of these men. So in Manggarai tradition is not telling the history of the descendants a daughter, which is told is ata one descent. This is 
because in depth the male genitals (penis) when making love/during sexual intercourse be in the womb. In addition, men who put descended. Generally in Manggarai tradition in case of inheritance, which is having the right entitled to inheritance of parents are boys.

The Reason of Manggarainese People Use Expression of Ata pe 'ang ata one at Whelping Ceremony in Manggarai Tradition

This term is used by the Manggarai society because: The term ata pe 'ang ata one used by the Manggarai people when a baby was born in Manggarai is traditions and a heritage that should be preserved. Manggarai people believe if it is not done then there will be itang (impact) in the form of the child was not normal. But if forgotten without the element of intent, for example, was born in health facilities then do not called/discussed.
The Manggarai Society more use symbolic language in traditional ceremonies and rarely reveal anything objects/things it directly on the object. The term ata pe'ang-ata one is a symbolic language. The Manggarai people use this term so that no direct mention of sex. It is because was considered impolite and very guilty at all if directly mention gender. It was a very basic reason, why the Manggarai people only mention ata pe'ang-ata one. Actually it was called genital use full to breed descent. Ata pe'ang was a symbol for women while ata one is the symbol for male. The term ata pe'ang-ata one was notification, because mothers who give birth are in the room while other people outside the room.

\section{Discussion}

Along with development of the era, Manggarai culture especially traditional ceremony in baby birth inch by inch not use by Manggarai 
society. It is because; today many of the Manggarai society are doing the process of maternity in health facilities such as public health centers and hospitals. It is tightened by the East Nusa Tenggara government through health department about maternity especially the suggestion to give birth in a health facility in 2010. By this rule, the majority of Manggarai societies give birth in a health facility. Babies who are born in health facilities does not use custom rules with the result that by itself an expression of ata pe'ang-ata one is not used. It is related with the theory of Dagul, wherein according to Dagul; culture tended to change in rhythm with development of sciences and technology which product by human being (Dagur, 2008:11).

Ata pe'ang-ata one is symbolism language which is used when a baby birth in Manggarai. Ata pe'ang (outsiders) is symbol to infants who sex female while ata one is symbol to infants who sex male. According to Deki, in symbolization on a fact of life according to conviction of Manggarai people entire of human life to collect inside symbols both in relationship inter fellow being, with the nature, in spite of the fact the supernatural. According to Deki also, besides as a symbolism language ata pe'ang-ata one also have relation with the conviction of Manggarai people. It is because as symbolization on a fact of life ata pe'ang-ata one is a real form of utterance. The symbols be visible in a material manner in form a particular things, picture, carved object, nor such as in form utterance or narrative (Deki, 2011:56). Symbols are part of semiotics. It is proved by Manning wherein he stated that semiotics is science of signs and symbols, such as body language (Manning, 1987). There are two symbols in this research 
among them ata pe'ang symbols to female and ata one symbol to male.

Ata pe'ang-ata one also have a meaning and there are two meanings which will be describe by the researcher in this study. For the first is Lexical meaning. Before the researcher describe more about lexical meaning in ata pe'ang-ata one, so previously the researcher will describe when the Manggarai people use utterances ata pe'ang-ata one. Ata pe'ang-ata one used by Manggarai people only at the moment a baby birth in Manggarai society and it is in form of oral language. Based on the lexical meaning the meaning of ata pe'angata one is:

Ata: Other people. So the meaning of words can be said ata has no relationship at all.

Pe'ang: outside. Sothe word pe'ang can be said to be outside.
One: in. So the word one can be said that to be inside.

So, based on the meaning of the word ata pe'ang, is other people who are outside while ata one means other people who were inside. It is related to the definition of lexical meaning by Kreidler. According to Kreidler lexical meaning is the meaning which based on the root of word/based meaning. Lexical meaning reveals the word meanings that are stored in mental lexicon (Kreidler: 1983).

The last is pragmatic meaning. Pragmatic meaning is the meaning which related with the context wherein in this study the context is traditional ceremony especially birth ceremony. Based on the definition so the pragmatic meaning of ata pe'ang ko ata one is: (a) the pragmatic meaning of ata pe'ang. A daughter when she married then she will go to keep up with her husband moved to the house / home and become part of 
her husband's family as well as forming a new generation in the family pertinent. It is a concrete manifestation of ata pe'ang. When she is married, she would to keep up with seki (custom rules) of her husband. Daughter (ata pe 'ang), will legal to keep up with her husband's family seki pass through "tempang pitak" (clean mud) ceremony. When she is married, she also does not have the authority again to have the inheritance of her parents. It is because she will be getting inheritance in place or her husband's family. Because she has formed a new family and already has a husband so she be said to be Woelanak wina, then she has the right and duty as what did explain by the researcher in findings. (b) The pragmatic meaning of ata one. When he is married, then he would take his wife to the house/home and his wife will follow seki of these men. So in Manggarai tradition is not telling the history of the descendants a daughter, which is told is ata one descent. Generally in Manggarai tradition in the case of inheritance, which is having the right entitled to inheritance of parents are boys. But in develop girls also can be inheritance in the form of giving.

Based on the explanations of ata pe'ang-ata one above so it is related with the context of Manggarai tradition especially the relation of ata pe'ang-ata one utterances with duty, right and family relation of Manggarai society. It is related with the theory of Adisutrisno. According to Adisutrisno, utterance meaning is also called pragmatic meaning that means the meaning of a sentence when it is used in communication by a speaker and hearer (Adisutrisno, 2008).

\section{Conclusion}

Based on the the findings and discussions, the researcher found that ata pe'ang - ata one is symbolism language in order to male 
and female wherein ata pe'ang refers

to the female while ata one refers to the male. Besides that the term of ata pe'ang-ata one still close related to the status of the authority in managing the household, genes, and the rights of ownership. The meaning of ata pe'ang-ata one is to differentiate sex, to clarifying role between ata one and ata pe'ang, to determine authority between ata one and ata pe'ang. In this case which more of organize is ata one, whereas ata pe'ang have duty to listening, to complemented all of duty of ata one. Besides that, ata one is source of water, source of water life to ata pe'ang. Manggarainese people use the term ata pe'ang -ata one in birth rituality so that do not direct mention of sex. Because the sex very wellthought-of Manggarai society.

Suggestions

Considering the importance of understanding the meaning of ata pe'ang-ata one in Manggarai tradition, some suggestions are made. Based on the result of this research, the researcher suggests for: (a) theoretically. Based on the result of this research, in theoretically the researcher suggests to pragmatic, meaning, and semiotic. (a) Practical. Based on the result of this research, in practical the researcher suggests to the English students, lecturer, and further researcher.

\section{Refferences}

Soekanto, S. 2012. Sosiologi: Suatu pengantar. Jakarta: Rajawali Pers

Nggoro, M. A. 2006. Budaya Manggarai: Selayang Pandang. Ende: Nusa Indah 
Dagur, B. A. 1997. Kebudayaan Manggarai: Sebagai Salah Satu Khasanah Kebudayaan Nasional. Surabaya: Ubhara Press

Deki, T. K. 2011. Tradisi Lisan Orang Manggarai: Membidik persaudaraan dalam bingkai sastra. Jakarta: Parhesia Institute Jakarta

Manning, K. P. (1987). Semiotics and fieldwork. Newbury Park, Cal.: Sage.

Oxford. (2015). Oxford Dictionaries: Language matters. English: Oxford University Press

Riley, Philip. 2007. Language, Culture and identity: An Ethnolinguistic Perspective. Great Britain: Athenaeum Press Ltd.,

Elmes. D. The Relationship between Language and Culture. National Institute of Fitness and Sports in Kanoya International Exchange and Language Education Center

Kreidler w. K. 1998. Introduction English: Semantics. London: Routledge

Adisutrisno W. D. 2008. Semantics: an introduction to the basic concepts. Yogyakarta: ANDI

Ayu P. N. Konsep hidup dan mati dalam leksikon khaul buyut tambi (kajian etnolinguistik di indramayu). Jurnal: Universitas Pendidikan Indonesia

Qudus. R. 2013. Analisis kohesi leksikal dalam novel dom sumurup ing banyu karya suparto brata. Jurnal: Program Studi Pendidikan Bahasa dan Sastra Jawa_Universitas Muhammadiyah Purworejo 83 
Pratiknyo. A. 2009. Istilah-istilah upacara perkawinan adat jawa bubak kawah dan tumplak punjen di kecamatan bendosari kabupaten sukoharjo (suatu kajian etnolinguistik). Skripsi: universitas Sebelas Maret Surakarta

Wahyuni, S. 2011. Qualitative Research Method: Theory and Practice. Jakarta: Penerbit Salemba

Mitchell, M. (2008). Conducting ethnographic research on language-like visual Communication. Bond University: Faculty of Humanities and Social Sciences

Creswell, W. J. 2003. Research Design: Qualitative, Quantitative, and Mixed Methods Approaches. USA: Copyright O 2003 by Sage Publications, Inc

Miles, B. M. and Huberman, M. A. 1994. Qualitative Data Analysis. USA: Sage Publications, Inc

Denzin, N. K. (1970). The Research Act in Sociology. Chicago: Aldine. 